\title{
УOBOЗНАВСТВO. NITEPATУPOBHABCTBO
}

\author{
УДК 81'25 \\ DOI https://doi.org/10.24919/2308-4863/36-3-13
}

\author{
Світлана РАДЕЦЬКА, \\ orcid.org/0000-0001-7308-8179
}

кандидат педагогічних наук, доцент, завідувач кафедри теорії та практики галузевого перекладу Херсонського національного технічного університету (Херсон, Україна) rad.svete1976@gmail.com

\author{
Валерія БАЛАБУХ, \\ orcid.org/0000-0002-3617-3128 \\ студентка магістратури кафедри теорії та практики галузевого перекладу \\ Херсонського начіонального технічного університету \\ (Херсон, Україна) kafedratphp@ukr.net
}

\section{ПРИРОДА СИМВОЛА ТА ХУДОЖНІЙ ПЕРЕКЛАД: НАРИС ПРОБЛЕМАТИКИ}

У статті охарактеризоване поняття «символу» та «художнього образу» й розглянуті їхні функиіональні властивості. Ці об'єкти подібні за своєю семіотичною структурою, використовуються в пересічних контекстах, включені у взаємодіючі системи, є формами і способами освоєння й перетворення дійсності. На відміну від художнього образу, що характеризується локальністю та індивідуальністю, естетичним вектором спрямованості, актуалізацією переосмислення, спрямованістю на людину, символ є універсальним і колективним поняттям, спрямованим на екзистениіальне.

Також були проаналізовані методичні підходи до аналізу символу при перекладі художнього тексту. Вони мають багато критеріїв, проте не всі з них прийняті та суттєві для всіх дослідників через те, шо значну роль відіграє мета того, хто береться за иеей аналіз. У нашій статті ми виділили ті аспекти, які є корисними і важливими для перекладача, а саме лише те, щчо дозволяє виділити символ у тексті; чітко розмежувати символ $i$ суміжні явища; визначити ступінь багатозначності того чи іншого символу; визначити місце символу у структурі оригінального тексту, щоб далі відтворити у тексті перекладу.

Визначною рисою функиіонування лінгвістичного символу в художньому тексті є розщирення $і$ варіювання його значення за рахунок навколишнього контексту. Спрямованість на дослідження символу в художньому тексті пов'язана з розумінням тексту як культурної комунікативної системи, яка завдяки образам, символам, які переходять із епохи до епохи, від тексту до тексту, накопичує $i$ зберігає величезний смисловий потенціал, необхідний для розуміння як тексту загалом, так і для трактування його окремих складників.

Ми встановили, щуо специфіка емоційності та експресивності символу полягає в ї̈ імпліцитності. Оскільки символ може мати у собі кілька образів і трактувати їх по-різному, перекладач повинен виділити всі образи, які показує той чи інший символ, та дати адекватний переклад. Тому у нашому подальшому дослідженні ми будемо аналізувати специфіку відтворення символів у перекладах художнього твору.

Ключові слова: символ, художній образ, переклад художнього твору, комунікативна система.

\author{
Svitlana RADETSKA, \\ orcid.org/0000-0001-7308-8179 \\ Candidate of Pedagogical Sciences, Associate Professor, \\ Head of the Department of Theory and Practice of Branch Translation \\ Kherson National Technical University \\ (Kherson, Ukraine) rad.svete1976@gmail.com
}

Valeria BALABUKH, Master's Student at the Department of Theory and Practice of Branch Translation Kherson National Technical University (Kherson,Ukraine) kafedratphp@ukr.net

\section{THE NATURE OF THE SYMBOL AND ARTISTIC TRANSLATION: AN OUTLINE}

The article describes the concept of "symbol" and "artistic image" and considers their functional properties. These objects are similar in their semiotic structure, are used in ordinary contexts, are included in interacting systems, are forms and methods of development and transformation of reality. In contrast to the artistic image, characterized by locality 
and individuality, aesthetic vector of orientation, actualization of rethinking, focus on man, the symbol is a universal and collective concept aimed at the existential.

Methodical approaches to the analysis of a symbol at translation of the art text were also analyzed. They have many criteria, but not all of them are accepted and relevant to all researchers due to the fact that the purpose of the person undertaking this analysis plays a significant role. In our article we have identified those aspects that are practically useful and important for the translator, namely, only what allows: to highlight the symbol in the text; clearly distinguish between the symbol and related phenomena; determine the degree of ambiguity of a symbol; determine the place of the symbol in the structure of the original text to further reproduce in the translated text.

A distinctive feature of the functioning of the linguistic symbol in the literary text is the expansion and variation of its meaning due to the surrounding context. The focus on the study of symbol in the literary text is associated with the understanding of the text as a cultural communicative system, which through images, symbols that move from era to era, from text to text, accumulates and retains enormous semantic potential needed to understand the text as a whole and for the interpretation of its individual components.

We found that the specificity of the emotionality and expressiveness of the symbol lies in its implicitness. Since a symbol can have several images and convey them in different ways, the translator must select all the images shown by a symbol and give an adequate translation. Therefore, in our further research we will analyze the specifics of the reproduction of symbols in translations of a work of art.

Key words: symbol, artistic image, translation of a work of art, communicative system.

Постановка проблеми. Проблема визначення символу в художній творчості 3 точки зору лінгвістики $є$ практично недослідженою і відповідно досить актуальною. У літературі накопичений різноманітний матеріал щодо проблеми символу, але здебільшого символи розглядаються в рамках дослідження більш широких філософських проблем (С. Аверінцев, Гегель, А. Ф. Лосєв, Е. Касcipep, Ф. Шеллінг, К. Г. Юнг та інші). Особлива увага приділялася проблемі розмежування символу з різними формами естетичного вираження й семантичними категоріями.

Аналіз досліджень. Теоретичні дослідження символу і символіки у мовознавстві здійснювали О. О. Потебня, О. Ф. Лосєв, Е. Сепір, Ю. М. Лотман, В. А. Маслова, М. П. Кочерган, Т. Г. Грушевицька, Н. Д. Арутюнова. Вчені трактують символ як предмет або слово, що умовно виражає суть якогось явища.

Метою статті є трактування символу, релевантне саме для художнього тексту через той факт, що універсального визначення поняття «символ» не існує, а правильне розуміння зазначеного поняття $є$ обов'язковою передумовою для подальшого адекватного перекладу при відтворенні текстів художньої літератури з однієї мови на іншу.

Виклад основного матеріалу. В сучасній науці існує безліч визначень терміну «символ». Насамперед це пов'язано 3 багатозначністю слова. У перекладі 3 грецької «символ» (“SYMBALLÖ”) - дієслово, що вказує на співпадання, з'єднання, злиття, зустріч двох начал у чомусь одному, i "symbolon" - як результат цієї зустрічі і такого поєднання, як вказівка на них, як знак тієї єдності. Символ означає «з'єднувати», «зливати», «зв'язувати», «знак, пізнавальна ознака». Відокремлюють символи універсальні, специфічні, випадкові, міфологічні, первісні, традиційні, архетипні, колективні, релігійні, ліричні, математичні, графічні та інші (Кулешова, Кантор, 2012: 95).

Теорії символу беруть початок в добу Античності. Відтоді і донині погляди на природу символу, його функції, роль і місце суперечливі, неоднозначні.

Аристотель трактував символ як знак, смислом якого є якийсь знак іншого роду чи іншої мови; цей знак - засіб передачі плану вираження адекватного чи метафоричного у план змісту, значення. Ці значення ясні, зрозумілі, піддаються класифікації. Платон вважав символ знаковим виразом якоїсь вищої, але не знакової сутності, значення якої не завжди фіксується, тому сутність образу можна вловити через посередність образів, які виникають на межі яснобачення.

У ХХ столітті теоретичні дослідження символу і символіки здійснили С. Аверінцев, Х. Керлот, О. Лосєв, Е. Сепір. Кожен із цих вчених, а також певною мірою В. Топоров, Г. Юнг по-своєму трактують символічно-міфологічні явища.

Своєрідна теорія міфу і символу належить О. Ф. Лосєву. Дослідник вважав: 1) символ - функція відображення дійсності; 2) символ - смисл дійсності; 3) символ - інтерпретація дійсності в людській свідомості; 4) символ - сигніфікація дійсності; 5) символ - перетворення дійсності. І якщо «міфологія - це втілена дійсність», то «символ субстанційне поєднання ідеального та реального. Це сама річ, за іiі ж суттю». Але «сутність речі $\epsilon$ сама ж річ, не тільки взята в тотожності сама із собою, а, оскільки ототожнювати можна тільки те, що різне, то смисл речі є сама річ, але взята водночас і в різниці із самою собою». За визначенням О. Лосєва, «символ» - така образна конструкція, яка може вказувати на будь-які межі небуття i, в тому числі, на «безмежжя». Варто мати на увазі, що «не можна провести межі поміж скінченним і нескінченним символом, адже, з одного 
боку, категорія символу скрізь і завжди скінченна, а 3 іншого, - нескінченна» (Лосев, 1995: 51).

Людина живе у світі символів із доісторичних, прадавніх часів. Символіка - одна із могутніх підвалин культури. Відомо, що справжнє мистецтво символічне. Проте символізм властивий не лише художній творчості, а й політиці, ідеології, освіті, моралі. Саме через це символи і символіку тлумачать на побутовому, філософському, естетичному, мовознавчому та інших рівнях. Ці різного роду тлумачення спричиняли відмінності у підході до визначення поняття «символ».

Символ має багатовікову історію, яка виявляється у сталості його значень та асоціацій. У процесі свого розвитку символ може накопичувати нові асоціації, але при цьому не втрачати старі, усталені. Перенесення значення, на якому базується символ, не залежить від індивідуальноавторського мислення, воно не $\epsilon$ «одноразовим», а навпаки характеризується тривалістю існування, стабільністю, наявністю «історії». Крім цього, однією із головних особливостей символу є присутність у ньому предметного значення, причому для символу важливе і пряме, і переносне значення, і загальне, і одиничне.

Символ засновано насамперед на живому спогляданні дійсності. Далі це чуттєве споглядання доходить ступеня абстрактного мислення, оскільки символ включає в себе усе, що $€$ характерним для останнього: чітке розрізнення й протиставлення елементів дійсності, чітке їх об'єднання в одне ціле, узагальнення чуттєвого досвіду і перетворення всієї почуттєвої дійсності на узагальнену закономірність. Наприкінці, абстрагуючи мислення, знову повертається до об'єктивної дійсності, яку полишило, тобто стає свого роду практикою.

Найбільш адекватною, прийнятною для нас $\epsilon$ дефініція символу, запропонована С. Аверинцевим: символ (гр. “symbolon” - «знак», «образ») у мистецтві - універсальна естетична категорія, яка розкривається через співставлення із суміжними категоріями художнього образу, знаку та алегорії. $\mathrm{y}$ широкому сенсі можна казати, що «символ $\mathrm{\epsilon}$ образ, взятий в аспекті своєї знаковості, і що він $є$ знак, наділений цією органічністю й невичерпною багатозначністю образу» (Аверинцев, 1983: 721).

Таке трактування символу, на наш погляд, доречне з кількох причин. Насамперед тому, що в художній літературі знаковість і образність переплетені, як, мабуть, ніде більше. Тому визначення С. Аверинцева дозволяє відшукувати символи серед багатьох інших явищ, але у певному контексті. Подібний підхід підкреслює і двополісність символу: поєднання конкретного та абстрактного. Абстрактне значення символу завжди повинно бути «заземлено», втілюватися в якомусь конкретному образі. Така сутність самого символу: єднання знаковості та образності, контекстуальної зумовленості та полісемантичності.

Предметний образ і глибинний зміст виступають у структурі символу як два полюси, що не мисляться один без одного. Переходячи у символ, образ стає «прозорим»- зміст немов «просвічує» крізь нього, даний як змістова глибина, смислова перспектива (Аверинцев, 1983: 497). Будь-яке зображення тільки тоді переростає у символ (i тут співпадають точки зору теологів, психологів), щоб залишився якийсь непізнаний аспект, що важко буде пояснити або визначити.

Таким чином, визначення поняття «символ», надане С. Аверинцевим, є найбільш адекватним для художнього тексту, адже саме його тлумачення бере до уваги переплетіння знаковості та образності у символі. У художньому творі (у нашому випадку - це роман Дж. Оруела «Колгосп тварин») будь-який символ $є$ не просто знаком, а й багатозначним образом.

Більшість дослідників проблеми символізму вказують на суто знаковий характер цього явища, пов'язаного 3 образним вираженням реального світу. С. Аверинцев цілком справедливо зазначає, що усякий образ є хоча б деякою мірою символом. Символ існує не тільки в мистецтві, але й у практичному житті. Таким чином, символ має багатозначний характер, тому його не можна ототожнювати 3 алегорією.

Співвідношення символу і художнього образу в теоретичному аспекті ускладнюється тим, що обидва поняття мають безліч трактувань, а відповідні їм явища існують у сферах, що пересікаються, і подібних контекстах, однак роль цих одиниць у мові культури різна, що вимагає їх чіткого розмежування, заснованого на суворому протиставленні понять. Зупинимося на найбільш близьких трактуваннях символу і художнього образу як знаків особливого роду, які специфічно відображають і перетворюють дійсність.

У семіотичному відношенні символ і художній образ подібні за своєю структурою і зв'язують приватне і загальне, конкретний предмет і абстрактну ідею. Подібність символу і художнього образу як знаків виявляється і у жорсткій зумовленості, органічній вбудованості цих одиниць до відповідних систем. Художній образ не несе ніякої певної думки сам по собі. Спроби встановити локальну функцію кожного образу в художньому цілому призводять до збіднення художнього 
сенсу. Художній образ означає більше, ніж він $€$, через його багатозначність саме внаслідок сполучення 3 іншими художніми образами (Родянская, Кожинов, 1962-1978: 363-369.). Аналогічний ефект справляють і символи: їх розгляд поза цілісним простором культури неминуче призведе до десимволізації, перетворення у власне знаки (Мамардашвили, Пятигорский, 1997: 101-102), а кодифікація символів свідомо передбачає фрагментарність дефініцій, досить умовне і віддалене відображення суті предмета, який позначається.

Крім того, естетичні системи проникають у символічні, збагачуючи смисловий простір культури, як і символічні - в естетичні, збагачуючи останні. У зв'язку із зазначеними вище подібностями виникає питання про співвідношення образного і символічного у цих знаках. На таке питання важко відповісти однозначно, оскільки без залучення образності жоден символ не може стати символом, а без прагнення до символічності жоден знак не може стати художнім образом.

А. Ф. Лосєв має свою точку зору, згідно 3 якою символ повинен розглядатися окремо від поняття «художнього образу». Він стверджує, що художній образ завжди заснований на символі, має автономно-споглядальну цінність, навіть 3 урахуванням реально-історичної та ідеологічної навантаженості твору. У «чистому» художньому образі загальне породжує нескінченний смисловий ряд, але, взятий у відриві від решти, такий образ конструює сам себе. Однак врахування того, що художній твір у відриві від позахудожньої дійсності фактично не існує, повертає міркування автора на шлях термінологічної дифузії: «Ідея $\epsilon$ символ відомого образу, а образ - символом ідеї, причому ця ідейна образність або образна ідейність сприймаються як єдине і нероздільне ціле» (Лосев, 1995: 116-119). Отже, критерій естетичного споглядання не може в цьому випадку використовуватися ізольовано.

Для розмежування розглянутих понять видається більш продуктивним зіставлення художнього образу i символу відносно гранично загальних особливостей їх функціонування. Під художнім образом розуміється естетична категорія, яка об'єднує спосіб і форму освоєння і перетворення дійсності у мистецтві (Эпштейн, 1987: 252-257). Гіпотетично, виникаючи в рамках авторської естетичної системи, художній образ може набувати значення, важливого для всієї культури, включатися у іiі символічну систему і таким чином символізуватися.

Слід зазначити, що символ, трансформований (актуалізований) у художньому образі, отримує при цьому необхідну для підключення до символічного простору культури частку предметності, відчутності. Стимулюючи уяву, художній образ змушує людину не стільки інтерпретувати символ, скільки переживати його. У цьому сенсі художній образ $є$ посередником між символічним (духовним) і безпосереднім (матеріальним, соціальним) аспектами людського існування.

Якщо розглядати символ як форму перетворення дійсності, то виникає інше співвідношення символу 3 художнім образом. Людині властиво наділяти навколишню їй реальність не властивими їй від природи характеристиками. Здатність символу і художнього образу висловлювати інші властивості речей, фіксувати ореол надпонятійності забезпечує людину усім необхідним для цього. Але якщо у випадку з художнім образом вектор перетворення є естетичним, то із символом цей вектор $є$ екзистенціальним. Художній образ забезпечує емоційну насиченість життя за допомогою її переміщення в систему координат прекрасного і потворного. Символ наділяє життя людини сенсом, оскільки надає матеріальним об'єктам духовно значущих компонент.

Якщо розглядати символ як спосіб освоєння дійсності, то знову виявляється його схожість із художнім образом. Об'єкт дійсності, який має місце в контексті художнього твору, вступає у специфічні зв'язки, відібрані і організовані автором. У результаті такої взаємодії отриманий художній образ виражає ті властивості об'єкта дійсності, які у складних відносинах самої дійсності не досить яскраві, щоб стати чітко помітними. Символ також робить виразним якийсь неясний, розпливчастий зміст, що активно використовується авторами для створення тканини художнього твору. Однак художній образ виникає винятково у контексті: будь-які зміни в структурі художнього твору призведуть до появи іншого образу. Символ від контексту конкретного твору практично не залежить, а будь-яке використання символу не скорочує, а збільшує кількість можливих взаємодій.

Таким чином, попри значну подібність, що міститься в наявності якогось непредметного змісту, надпонятійного сенсу, що дозволяє їм виступати формами і способами освоєння й перетворення дійсності, художній образ і символ відрізняються як локальне і універсальне, індивідуальне і колективне, естетичне і екзистенціальне, актуалізує переосмислення і фокусує осмислене, звернене до людини і адресоване світу.

Методичні підходи до аналізу символу при перекладі художнього тексту мають багато критеріїв, проте не всі вони прийняті та суттєві для усіх дослід- 
ників. Значну роль відіграє мета того, хто береться за цей аналіз. Для перекладача практично корисним і важливим виступає лише те, що дозволяє:

1) виділити символ у тексті;

2) чітко розмежувати символ і суміжні явища;

3) визначити ступінь багатозначності того чи іншого символу;

4) визначити місце символу у структурі оригінального тексту, щоб далі відтворити у тексті перекладу (Новикова, Шама, 1996: 34).

Будь-який символ у художньому тексті повинен відповідати певним критеріям, а саме: володіти асоціативністю та культурною детермінованістю, емоційністю, бути багатозначним, відносно стійким і контекстуально зумовленим. При цьому кожний із названих критеріїв має і свою специфіку щодо символіки саме художнього тексту.

Специфіка узагальненості і конкретності символу в художньому тексті реалізується у тому, що символ не може мати лише конкретне або лише відволіковно-загальне значення. Він їх ніби поєднує. Специфіка емоційності та експресивності символу полягає в її імпліцитності (згорнутості). Оскільки символ може мати у собі кілька образів і трактувати їх по-різному, то перекладач повинен виділити усі образи, які показує той чи інший символ, і дати їм адекватний переклад.

Специфіка перекладу багатозначності символу в художньому тексті виявляється у тому, що символ, існуючи протягом століть, накопичує додаткові значення, не втрачаючи безслідно вже існуючих, при цьому символ не статичний у рамках однієї культури і не $є$ тотожнім сам собі в різних культурах або у діахронії. У результаті створюється додаткова можливість тлумачення символу у вихідному тексті, що розширює коло можливих відповідностей у перекладному тексті.

Проте ієрархія значень всередині символу завжди детермінована цією національно-культурною системою. Тому при перекладі можна скористатися аналогічним символом культури перекладу, але потрібно врахувати диференційні властивості цього символу у двох культурах. При цьому для перекладного тексту релевантними $€$ всі види контекстів, у які включений такий символ.

Словники орієнтовані все-таки, скоріше, на інтегральні, ніж на диференційні значення символу. Але перекладач шукає відповідності іншонаціональному символу в системі іншої мови та іншої культури. А тому для нього диференційні властивості бувають не менш, якщо не більш суттєві практично.

Обов'язковим під час аналізу символу є метод функціональний або контекстуальний, адже пере- кладач має справу із символом не як зі словниковою одиницею, а із символом всередині художнього тексту. Цей метод передбачає аналіз символіки на трьох рівнях:

1) гіпотекстовий (фонетичний, графічний, морфологічний, лексико- семантичний, фразеологічний, синтаксичний контексти);

2) текстовий (сюжетний, композиційний контексти);

3) гіпертекстовий (контекст творчості певного автора і перекладача, жанровий контекст i контекст літературного напряму (традиції) як складник національно-культурного контексту) (Потебня, 2000: 170).

У нашому випадку із романом Дж. Оруела треба пояснити значення символіки у такому жанрі як сатира. Сатира - мистецтво критики об' єкта через глузування і презирство. Це дотепна або гумористична «тональність», де гумор використовується, щоб звернути увагу на деяку проблему, а сатира - фантастична розповідь-алегорія. «Колгосп тварин» Оруела - гумор, сарказм, притча, яка спромоглася набути форми «іронічної антиутопії». Замість розповіді про проблеми людини, особистості Оруел поміщає тварин у людську ситуацію.

Простота викладів, вбрана в алегорію, фантастичні елементи (тварини думають і обговорюють, керують фермою, будують вітряний млин) дозволяє виразно проілюструвати людські проблеми, проблеми волі. Дж. Оруел описує яскраві, емоційно виразні сцени, образні описи, що створюють дійсно драматургічну напругу, навіть своєрідний ліризм, однак головне у них - пафос викриття і заперечення антилюдського пристрою, пафос, що часто виливається у відверту публіцистику. Матеріал дійсності, проти якого виступає Оруел, настільки актуальний, животворний, що він ізсередини руйнує літературність, вривається в текст живими, легко пізнаваними фактами, змушує автора звертатися до відкритої політичної публіцистики.

Висновки. Поняття «символ» досить широко представлене в сучасних термінологічних словниках із лінгвістики, але його трактування відрізняється багатозначністю і суперечливістю. Це можна пояснити насамперед об' єктивною складністю його змісту. У термінологічній лексикографії не виявляється єдності в розумінні символу.

Ми розглянули кілька точок зору з приводу природи лінгвістичного символу. Під лінгвістичним символом може розумітися умовне позначення будьякої одиниці (графічні зображення морфем у слові або букві алфавіту як аналоги математичних символів) або такий тип символу - це досить жорсткий 
спосіб взаємодії фонетичного, лексичного та граматичного підрівнів мови у процесі осмислення словесних знаків. Особливе місце займає дослідження лінгвістичного символу в художньому тексті.

Специфічною рисою функціонування лінгвістичного символу в художньому тексті є розширення і варіювання його значення за рахунок навколишнього контексту. Спрямованість на дослідження символу в художньому тексті пов'язана із розумінням тексту як культурної комунікативної системи, яка завдяки образам, символам, які переходять із епохи до епохи, від тексту до тексту, накопичує і зберігає величезний смисловий потенціал, необхідний для розуміння як тексту загалом, так і для трактування його окремих складників. Однак один i той самий символ може мати різне, часом протилежне, значення в идіостиле письменників і поетів не тільки віддалених один від одного в часовому плані, а й у тих, чия творчість хронологічно близька.

Ми розглянули функціональні властивості символу і художнього образу. Ці об'єкти подібні за своєю семіотичною структурою, використовуються у пересічних контекстах, включені у взаємодіючі системи, є формами і способами освоєння і перетворення дійсності. На відміну від художнього образу, що характеризується локальністю та індивідуальністю, естетичним вектором спрямованості, актуалізацією переосмислення, спрямованістю до людини, символ є універсальним і колективним, спрямованим на екзистенціальне і фокусує осмислене й адресоване світу.

У подальшому нашому дослідженні ми будемо розглядати більш детально специфіку відтворення символів як специфічних лексико-семантичних характеристик ідіостилю Дж. Оруела при перекладі його епохального твору «Колгосп тварин».

\section{СПИСОК ВИКОРИСТАНИХ ДЖЕРЕЛ}

1. Аверинцев С. С. Символ. Философский энциклопедический словарь. Москва: Сов. Энциклопедия, 1983.952 с.

2. Кулешова О. В., Кантор В. К. О сошедшем с ума разуме. К пониманию контрутопии. Культурология. 2012. № 3. C. 97-101.

3. Лосев А. Ф. Проблема символа и реалистическое искусство. Москва : Искусство, 1995. 320 с.

4. Мамардашвили М. К., Пятигорский А. М. Символ и сознание. Метафизические рассуждения о сознании, символике и языке. Москва : Школа «Языки русской культуры», 1997. 213 с.

5. Новикова М. О., Шама І. Н. Символика в художественном тексте. Символика пространства (на материале «Вечеров на хуторе близ Деканьки» Н. В. Гоголя и их английских переводов) : учеб. пособие. Запорожье : СП «Верже», 1996. $210 \mathrm{c}$

6. Образ художественный. Краткая литературная эничиклопедия: у 9 т. / гл. ред. А. А. Сурков. Москва : Советская энциклопедия, 1968. Т. 5. С. 363-369.

7. Потебня А. А. Символ й миф в народной культуре. Москва : Лабиринт, 2000. 480 с.

8. Эпштейн М. Н. Образ художественный. Литературный энциклопедический словарь. Москва : Советская энциклопедия, 1987. С. 252-257.

\section{REFERENCES}

1. Averintsev S. S. Simvol. (Symbol. Philosophical encyclopedic dictionary). Moscow : Sov. Encyclopedia, 1983. 952 p. [in Russian].

2. Kuleshova O. V., Cantor V. K. O soshedshem s uma razume. K ponimaniyu kontrutopii (About a mad mind. To the understanding of countertopia). Culturology. 2012. № 3. P. 97-101 [in Russian].

3. Losev A. F. Problema simvola i realisticheskoye iskusstvo. (The problem of symbol and realistic art.). Moscow : Iskusstvo, 1995. 320 p. [in Russian]

4. Mamardashvili M. K., Pyatigorsky A. M. Simvol i soznaniye. Metafizicheskiye rassuzhdeniya o soznanii, simvolike i yazyke. (Symbol and consciousness. Metaphysical arguments about consciousness, symbolism and language). Moscow : School "Languages of Russian culture", 1997. 213 p. [in Russian].

5. Novikova M. O., Shama I. N. Simvolika v khudozhestvennom tekste. Simvolika prostranstva (na materiale "Vecherov na khutore bliz Dekan'ki" N. V. Gogolya i ikh angliyskikh perevodov). (Symbolism in an artistic text. Symbolism of space (on the material "Evenings on a farm near Dekanka" by N. V. Gogol and their English translations). Zaporozhye : CP "Verzhe", 1996. 210 p. [in Russian]

6. Obraz khudozhestvennyy. Kratkaya literaturnaya enciklopediya: in 9 T. (The image is artistic. A brief literary encyclopedia.) / gl. red. A. A. Surkov. Moscow : Soviet encyclopedia, 1968. T. 5. P. 363-369 [in Russian].

7. Potebnya A. A. Simvol y mif v narodnoy kul'ture. (Symbol and myth in folk culture). Moscow : Labyrinth, 2000.480 p. [in Russian].

8. Epstein M. N. Obraz khudozhestvennyy. (The image is artistic). Moscow : Soviet encyclopedia, 1987. P. 252-257 [in Russian]. 